\title{
Valorization of a Bio-Stabilized Municipal Solid Waste Amendment for Faba Bean (Vicia faba L.) Fertilization
}

\author{
Sara Martinez ${ }^{1,2, *}$, Sara Sánchez-Moreno ${ }^{3}$, Jose Luis Gabriel ${ }^{3,4}{ }^{\oplus}$, Cristina Álvarez $^{5}$ and Maria del Mar Delgado ${ }^{3}$ \\ 1 Department of Land Morphology and Engineering, Universidad Politécnica de Madrid, 28040 Madrid, Spain \\ 2 Department of Engineering, Aviation and Technology, Saint Louis University Madrid, 28003 Madrid, Spain \\ 3 Department of Environment and Agronomy, Instituto Nacional de Investigación y Tecnología Agraria y \\ Alimentaria (INIA-CSIC), 28040 Madrid, Spain; sarasm@inia.es (S.S.-M.); gabriel.jose@inia.es (J.L.G.); \\ delgado@inia.es (M.d.M.D.) \\ 4 Centro de Estudios e Investigación para la Gestión de Riesgos Agrarios y Medioambientales \\ (CEIGRAM-UPM), 28040 Madrid, Spain \\ 5 Urbaser S.A., Spain, 28031 Madrid, Spain; calvarezr@urbaser.com \\ * Correspondence: s.martinezd@alumnos.upm.es
}

check for updates

Citation: Martinez, S.; SánchezMoreno, S.; Gabriel, J.L.; Álvarez, C.; Delgado, M.d.M. Valorization of a Bio-Stabilized Municipal Solid Waste Amendment for Faba Bean (Vicia faba L.) Fertilization. Agriculture 2021, 11, 1109. https://doi.org/ 10.3390/agriculture11111109

Academic Editor: Vasileios Antoniadis

Received: 1 October 2021

Accepted: 3 November 2021

Published: 6 November 2021

Publisher's Note: MDPI stays neutral with regard to jurisdictional claims in published maps and institutional affiliations.

Copyright: (c) 2021 by the authors. Licensee MDPI, Basel, Switzerland. This article is an open access article distributed under the terms and conditions of the Creative Commons Attribution (CC BY) license (https:// creativecommons.org/licenses/by/ $4.0 /)$.

\begin{abstract}
The valorization of municipal solid waste (MSW) can serve as an organic amendment in agriculture while reducing solid waste accumulation in the environment. This research aimed to evaluate the valorization of a bio-stabilized MSW amendment for the production of faba bean (Vicia faba L.) crop. For this purpose, biomass production and growth, as well as, seed yield and seed components, seed nutrient accumulation, plant pigments, soil properties, and microorganisms were evaluated in comparison with faba bean mineral fertilization in a greenhouse experiment. The results demonstrated that the bio-stabilized MSW amendment achieved similar biomass production, plant growth, seed yield, nitrogen and protein content, and pigment content as the mineral fertilization treatment. On the other hand, the organic fertilization did not exhibit significant effects on the yield components number of pods per plant, and number of seeds per pod, and nutrient accumulation in seeds with respect to mineral and control treatments in both soils. Sandy and clay soil properties were improved in the organic treatments in comparison with the control soils by increasing soil organic carbon, nitrogen, and other soil nutrients, and providing a suitable $\mathrm{pH}$ for faba bean growth. Additionally, biological activity was favored by applying this source of organic fertilizer, enriching the nematode community. Reusing bio-stabilized MSW for agronomical purposes can add value to this waste product, serving as an effective alternative to mineral fertilizers in faba bean cultivation.
\end{abstract}

Keywords: organic fertilization; soil; mineral fertilization; soil amendment; agriculture

\section{Introduction}

Exponential population growth and urbanization have led to fast waste generation and accumulation. Currently, 2.01 billion tons of municipal solid waste (MSW) are generated worldwide each year and it is predicted to increase to 3.4 billion tons by 2050 if current conditions remain unchanged [1]. Extremely alarming is the fact that $33 \%$ of the MSW generated is mismanaged, causing subsequent negative social, economic, and environmental impacts [1,2]. Even when the MSW is collected, most of this waste is disposed of in conventional ways, such as in landfills and incinerators [2], despite their detrimental impacts on the environment [3-5] and being regarded as not favorable disposal options for biodegradable waste [6].

In light of the environmental burdens exhibited by MSW current disposal options, attention has recently been focused on exploring and fostering alternative waste management strategies. The organic fraction of the MSW is a valuable source of organic matter and nutrients, which is worth reusing and recycling for other applications [7]. In this way, MSW valorization can be achieved through bio-stabilization processes, such as composting and 
digestion, which are common methods applied worldwide to recover organic waste [8,9]. Regarding their applications, bio-stabilized amendments have been used in agriculture, horticulture, and soil remediation [10,11]. Some investigations have been carried out to study the effects of compost, which is the most extended bio-stabilized product, on crop growth. The use of compost has been studied for its application in agriculture, for example for cereal production, such as wheat [12,13], barley [14], and maize [15,16], and in horticulture $[17,18]$. In addition, compost is considered a nutrient-rich fertilizer useful for land restoration and improving soil quality [19].

Regarding crop production, faba bean (Vicia faba L.) is one of the most globally significant leguminous crops. The subspecies known as tick bean or pigeon bean (Vicia faba L. spp. minor) and horse bean (Vicia faba L. spp. equina) are mainly used as animal feed, while the subspecies broad bean (Vicia faba L. spp. major) is used for human consumption [20]. Faba bean seeds are highly nutritious because of their high protein and starch content [21]. Known as broad beans, faba beans' production worldwide was approximately 4.4 million tons in 2019 [22]. In agriculture, the cultivation of faba bean extends around the world and its benefits in crop rotation systems by reducing the use of mineral nitrogen fertilizers, reducing greenhouse emissions, improving soil properties and fertility, and providing higher yields for the following crops has been demonstrated [23]. Research has been conducted with regards to faba bean fertilization and nutrient supply [24,25]. Pötzsch et al. [26] studied sulfur fertilization on seed yield. Additionally, Barłóg et al. [27] investigated the effect of soil potassium availability and sulfur fertilization, concluding that potassium-rich soils favor dry matter accumulation and that sulfur application can increase seed yield in potassium poor soils. Other micronutrients have been identified to be essential for faba bean yield [28]. Depending on the variety, higher phosphorus utilization efficiency can result in higher grain and biomass yields [29].

In faba bean cultivation, studies have been carried out to determine the effects of organic fertilizers on crop yield, seed quality, and soil fertility. Cucci et al. [30] investigated the application of three organic fertilization rates with non-composted wet olive pomace combined with mineral fertilization and determined that applying $140 \mathrm{Mg} \mathrm{ha}^{-1}$ of organic fertilizer and half mineral fertilizer achieved the same productivity results as full mineral fertilization. Similarly, rice straw with poultry manure and oilseed rape cake compost proved to not only increase faba bean growth and yield but also improve the soil's physicalchemical properties [31]. Compost from by-products can be an alternative to mineral fertilizers, improving plant development and increasing faba bean production [32].

In this context, this research aims to evaluate the application of a bio-stabilized amendment obtained from the organic fraction of MSW as an organic fertilizer on faba bean and identify its effects on crop biomass production, seed quality, and soil properties in comparison with mineral fertilization and two types of soils, sandy and clay soils. Additionally, the evaluation of the nematode community was carried out to provide important insights on soil fertility, and soil food web structure and complexity.

\section{Materials and Methods}

\subsection{Plant Cultivation}

The experiments with faba bean (Vicia faba var. Claro de Luna) were conducted under greenhouse conditions at the National Institute for Agricultural Research (INIA), sited in Madrid (Spain). Two types of soils were used for these experiments, sandy soil (92\% sand) and clay soil (35\% clay and 37\% loam) (Table 1). The characteristics of both soils before faba bean cultivation are shown in Table 1. Eighteen plastic pots of twelve liters of capacity were used in total. The treatments consisted of two types of fertilization, mineral and organic, and the control without fertilization. Each treatment was carried out with the two types of soils. The pots were arranged in a split-plot design with three replicates. Mineral fertilization was applied at a dose of $2 \mathrm{~g} \mathrm{pot}^{-1}$ of complex fertilizer N-P-K (15-15-15). Organic fertilization was carried out using a commercial bio-stabilized amendment from MSW provided by the company URBASER [33] (Table 1). The bio- 
stabilization process carried out to obtain this commercial product is similar to composting. The difference between this amendment and compost relies on the fact that, according to a Spanish regulation, compost implies a selective collection of material, while in this case non-source separated municipal solid wastes were used [34]. The bio-stabilized amendment application was $115 \mathrm{~g} \mathrm{pot}^{-1}$. As the faba bean is a legume, both fertilizer rates were adjusted based mostly on the phosphorous rate (around $41 \mathrm{~kg} \mathrm{P}_{2} \mathrm{O}_{5} \mathrm{ha}^{-1}$ for the organic and 50 for the mineral) as the most limiting nutrient, in an attempt to avoid large differences in mineral nitrogen application (around $66 \mathrm{~kg} \mathrm{~N} \mathrm{ha}^{-1}$ for the organic and 50 for the mineral).

Table 1. Physico-chemical properties of the organic amendment (bio-stabilized municipal solid waste amendment), sandy soil, and clay soil in dry matter.

\begin{tabular}{|c|c|c|c|}
\hline Parameter & Organic Amendment & Sandy Soil & Clay Soil \\
\hline Humidity (\%) & 78.8 & 15.90 & 24.23 \\
\hline Ashes (g/kg) & 39.00 & - & - \\
\hline $\mathrm{pH}, 1: 2.5 \mathrm{H}_{2} \mathrm{O}$ & 6.80 & 6.35 & 6.50 \\
\hline E.C., $1: 5 \mathrm{H}_{2} \mathrm{O}(\mathrm{dS} / \mathrm{m})$ & 5.59 & 0.07 & 0.08 \\
\hline Humic acids (\%) & 8.30 & - & - \\
\hline Fulvic acids (\%) & 8.00 & - & - \\
\hline Humic extract (\%) & 16.00 & - & - \\
\hline Organic carbon (\%) & 17.46 & 0.41 & 0.63 \\
\hline Organic matter $(\%)$ & 30.01 & 0.71 & 1.09 \\
\hline N Kjeldahl (\%) & 1.29 & 0.06 & 0.07 \\
\hline Ratio C/N & 13.48 & 11.80 & 9.90 \\
\hline $\mathrm{N}-\mathrm{NH}_{4}^{+}(\mathrm{mg} / \mathrm{kg})$ & 3174.5 & 3.64 & 2.73 \\
\hline $\mathrm{N}-\mathrm{NO}_{3}-(\mathrm{mg} / \mathrm{kg})$ & 208.32 & 11.13 & 0.55 \\
\hline $\mathrm{P}_{2} \mathrm{O}_{5}$ total $(\mathrm{g} / \mathrm{kg})$ & 2.1 & 0.7 & 0.6 \\
\hline $\mathrm{K}_{2} \mathrm{O}$ total $(\mathrm{g} / \mathrm{kg})$ & 10.9 & 3.3 & 4.6 \\
\hline $\mathrm{CaO}$ total $(\mathrm{g} / \mathrm{kg})$ & 68.6 & 33.1 & 23.3 \\
\hline $\mathrm{MgO}$ total $(\mathrm{g} / \mathrm{kg})$ & 69.7 & 3 & 3.1 \\
\hline Na total $(\mathrm{g} / \mathrm{kg})$ & 7.8 & 0.2 & 0.2 \\
\hline $\mathrm{Al}(\mathrm{mg} / \mathrm{kg})$ & 2600.00 & - & - \\
\hline $\mathrm{Fe}(\mathrm{mg} / \mathrm{kg})$ & 5010.00 & 2544.00 & 1222.00 \\
\hline $\mathrm{Co}(\mathrm{mg} / \mathrm{kg})$ & $<1.00$ & - & - \\
\hline $\mathrm{Mn}(\mathrm{mg} / \mathrm{kg})$ & 92.40 & 81.00 & 155.8 \\
\hline $\mathrm{Zn}(\mathrm{mg} / \mathrm{kg})$ & 140.00 & 15.00 & 19.32 \\
\hline As $(\mathrm{mg} / \mathrm{kg})$ & 1.70 & - & - \\
\hline $\mathrm{S}(\mathrm{mg} / \mathrm{kg})$ & 6822.80 & - & - \\
\hline $\mathrm{Cu}(\mathrm{mg} / \mathrm{kg})$ & 92.40 & 11.00 & 13.9 \\
\hline $\mathrm{Cr}(\mathrm{mg} / \mathrm{kg})$ & 31.90 & 5.60 & 5.95 \\
\hline $\mathrm{Ni}(\mathrm{mg} / \mathrm{kg})$ & 5.40 & 4.05 & 4.63 \\
\hline Mo (mg/kg) & $<1.00$ & - & - \\
\hline $\mathrm{Pb}, \mathrm{Cd}(\mathrm{mg} / \mathrm{kg})$ & 26.00 & $<0.20$ & $<0.20$ \\
\hline
\end{tabular}

A Spanish variety with early maturity and good resistance to cold conditions (Claro de Luna) was used in these experiments. The faba beans were sown at the end of October 2019 , four seeds per pot. Throughout the experiment, plants were watered, maintaining a humidity of approximately $60 \%$ of the soil's water-holding capacity, and kept weed-free. Crop growth was monitored from November until faba bean seeds were collected at the end of May.

\subsection{Soil and Plant Physical and Chemical Analyses}

Soil samples from each pot were passed through a $2 \mathrm{~mm}$ sieve before the analysis, homogenized, and kept in the laboratory at $4{ }^{\circ} \mathrm{C}$ before analyzing. Standard methods were used for carrying out the physical and chemical analyses. A glass electrode ( $\mathrm{pHmeter}$ BASIC20, Crison, Barcelona, Spain) using a soil water suspension of 1:2.5 (w/v), was used for measuring the $\mathrm{pH}$. The electrical conductivity (E.C.) was determined with a conductometer (soil/water ratio, 1:5.0: conductometer CDM3 Radiometer, Copenhagen, 
Denmark) at $25^{\circ} \mathrm{C}$ [35]. The total Kjeldahl Nitrogen (N) [36] was determined following the Kjeldahl method and inorganic nitrogen $\left(\mathrm{NH}_{4}{ }^{+} \mathrm{N}\right.$ and $\left.\mathrm{NO}^{-}{ }^{-} \mathrm{N}\right)$ was determined by the Bremner method, using airstreams distillation [37]. The Walkley and Black method [38] was applied to obtain the organic carbon. The elements $\mathrm{P}, \mathrm{K}, \mathrm{Ca}, \mathrm{Mg}$, and heavy metals $\mathrm{Fe}, \mathrm{Mn}, \mathrm{Cu}, \mathrm{Zn}, \mathrm{Pb}, \mathrm{Ni}, \mathrm{Cr}$, and $\mathrm{Cd}$ were extracted with acids and determined using an inductively coupled argon plasma emission spectrometry (CPOES, Perkin Elmer, Waltham, MA, USA) [39].

At the end of May, all faba bean plants were collected to analyze the main yield and yield components. Fresh faba bean seeds and pods were counted to obtain the number of seeds per pod, pods per plant, and seeds per plant. Faba bean seeds and biomass were dried in an oven until $12 \%$ moisture and weighted for dry matter yield determinations. For nitrogen and protein content, the seeds were ground into a fine powder with a laboratory mill. The total nitrogen was determined by the Kjeldahl method and converted to protein by multiplying the total nitrogen concentration by 6.25 [40]. To measure the chlorophyll, flavonols, and anthocyanins content of each faba bean plant, the non-destructive Dualex leaf clip sensor was used [41]. For nutrient accumulation in faba bean seeds, the milled seeds were analyzed to determine the macronutrients $\mathrm{Ca}, \mathrm{P}, \mathrm{K}, \mathrm{Mg}$, and the micronutrients $\mathrm{Fe}, \mathrm{Mn}, \mathrm{Zn}, \mathrm{Cu}$ by acid digestion and determined using an inductively coupled argon plasma optical emission spectrometry (CPOES) [39].

\subsection{Nematodes Analysis}

Nematodes were extracted from $200 \mathrm{~g}$ of fresh soil through a modification of the Baermann funnel method [42]. All nematodes in each sample were then counted under a dissecting microscope, and at least 150 nematodes in each sample were identified to the genus or family level at $400-1000 \times$ in a light microscope following [43]. A soil subsample of $25 \mathrm{~g}$ was oven-dried at $70{ }^{\circ} \mathrm{C}$ to calculate soil moisture, and nematode abundances were expressed as the No. of individuals per $100 \mathrm{~g}$ of dry soil.

The nematode taxa were classified into five trophic groups: bacterivores, fungivores, herbivores, omnivores, and predators. Besides, they were classified into five colonizerpersister (c-p) groups [44]. The c-p scale classifies nematode families into five groups from c-p 1-c-p 5, representing a scale from $r$ to K strategists. C-p 1 nematodes are enrichment opportunistic, present high reproduction rates, lay large numbers of eggs, and rapidly increase their populations following the bacterial blooms that occur in soils after organic enrichment. Nematodes in groups c-p 2-c-p 5 progressively show longer generation times, lower numbers of eggs, and higher sensitivity to soil disturbance and pollution. The joint classification of trophic and c-p groups classifies nematodes into functional groups [45].

Based on the abundance of nematode taxa, four ecological indices were calculated [45,46]. The Enrichment Index (EI) is based on the relative abundances of enrichment-opportunistic nematodes, and is used as an indicator of the activity of the bacterial-mediated decomposition channel and thus soil fertility. The Structure Index (SI) is based on the abundances of sensitive predator and omnivore nematodes and is an indicator of soil food web structure and complexity. The graphical representation of the EI vs. the SI values provides a soil food web diagnosis tool, by which the soil food web can be classified as disturbed (poor complexity and highly enriched, quadrat (A)), maturing (high complexity and highly enriched, quadrat (B)), structured (high complexity and low fertility, quadrat (C)), and degraded (low structure and fertility, quadrat (D)) [45]. The enrichment and the structure metabolic footprints, based on the biomass of the enrichment-opportunistic nematodes (enrichment metabolic footprint, (EMF)) and of omnivore and predator nematodes in high soil food web levels (structure metabolic footprint, (SMF)) are plotted as rhombus around the position of the EI, and SI in the biplot. The width and height of the rhombus are indicators of the biomass of nematodes in such functional groups (enrichment and complexity indicators, respectively). 


\subsection{Statistical Analysis}

Data were submitted to a statistical analysis by using the IBM SPSS software (version 25) [47]. A one-way analysis of variance (ANOVA) was performed to compare the effects of fertilization on the measured variables. Significant differences were determined using the Tukey HSD test at $p=0.05$.

Factorial ANOVAs were used to assess the effects of soil treatments and soil type on nematode taxa abundances and ecological indicators. Data were log-transformed before the analysis to achieve normality. The statistical analyses for nematodes were performed on the R statistical software (version 4.0.5) [48].

\section{Results and Discussion}

\subsection{Faba Bean Growth and Biomass Production}

The bio-stabilized MSW amendment showed a positive effect on the biomass production of faba bean plants with respect to the control treatments (Table 2). Although values showed that plant biomass production increased $38 \%$ in the sandy soil and $21 \%$ in the clay soil with the bio-stabilized MSW amendment compared with mineral fertilization, these results were not significant. Both types of fertilization, mineral and organic, resulted in higher biomass production than the unfertilized treatment (control). The significant influence of fertilization conditions on biomass production was in agreement with other authors. In previous investigations it was observed that the unfertilized plants (control) exhibited significantly lower biomass production than plants with organic fertilization with bio-stabilized amendments, evidencing the benefit of applying a nutrient source [30,32].

Table 2. Effect of organic (bio-stabilized MSW amendment) and mineral fertilization on faba bean biomass yield in sandy soil and clay soil (mean \pm SD).

\begin{tabular}{ccc}
\hline Soil Type & Fertilization & Biomass Production (g/Plant) \\
\hline Sandy & Control & $6.52 \pm 0.24 \mathrm{a}$ \\
& Mineral & $10.30 \pm 0.32 \mathrm{ab}$ \\
Clay & Organic & $14.23 \pm 0.39 \mathrm{~b}$ \\
& Control & $10.31 \pm 0.29 \mathrm{a}$ \\
& Mineral & $13.04 \pm 0.18 \mathrm{ab}$ \\
& Organic & $15.84 \pm 0.10 \mathrm{~b}$ \\
\hline
\end{tabular}

Mean values with different letters in the same row vary significantly $(p<0.05$, Tukey HSD test).

With respect to plant growth, for faba bean plants grown in sandy soil (Figure 1), the highest height at the end of the trials was achieved with the mineral fertilization, but the differences with respect to the organic fertilization were not significant. A common aspect found in both soils was that the control treatments exhibited lower heights than the fertilized treatments. In the sandy soil, the control was $21 \%$ shorter than the mineral treatment, and in the clay soil, plants were $12 \%$ shorter than the organic treatment with the bio-stabilized MSW amendment. For faba bean plants grown in the clay soil (Figure 1), the organic treatment with the bio-stabilized MSW amendment resulted in the highest height at the end of the trials. The growth differences between mineral and organic treatments in the clay soil were not significant, the organic fertilization's height was 7\% higher than the mineral. Plant heights for both soils at the end of the experiment were in accordance with that reported for faba beans $[49,50]$. Fertilization plays an important role in increasing plants' growth [51] and in this investigation, both fertilizers resulted in a similar plant length. A similar result was obtained by Cucci et al. [26], where the application of mineral fertilization obtained slightly higher heights than plants with organic fertilization, but without a significant difference. 


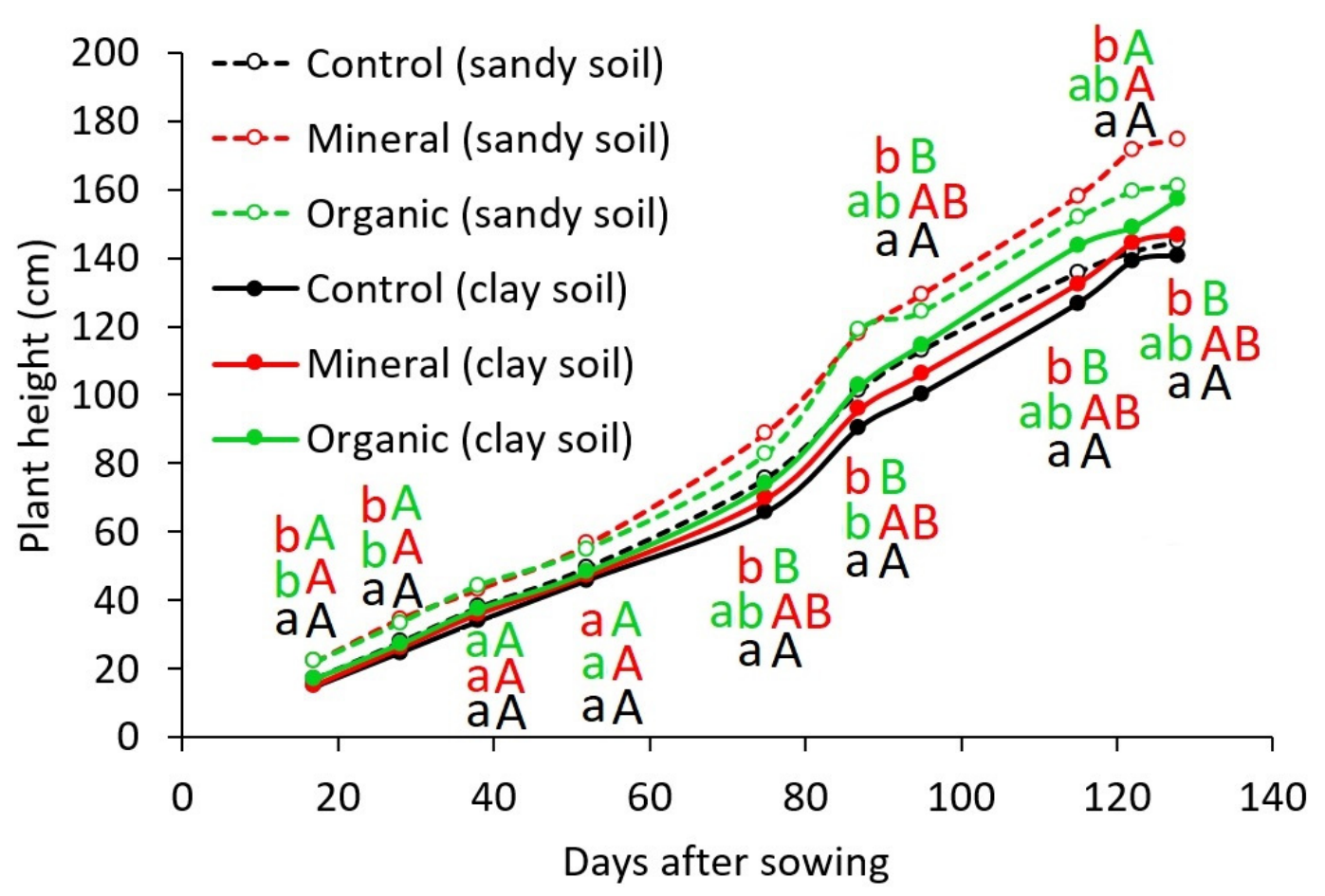

Figure 1. Effect of organic (bio-stabilized MSW amendment) and mineral fertilization on faba bean growth in sandy or clay soils. Different letters at each date indicate significant differences according to the Tukey HSD test at $p \leq 0.05$, lower case letters define sandy soil and capital letters define clay soil.

In this experiment, the organic treatment with the bio-stabilized MSW amendment in the sandy soil achieved the highest number of seeds per plant (Table 3). Significant differences were observed between the organic treatment with the bio-stabilized MSW amendment and the control, while these differences with respect to the mineral fertilization were not significant. A similar effect was obtained for the seed yield in the sandy soil. The use of fertilizers led to an increase in the seed yield with respect to the control, but there were no significant differences between the treatment with mineral fertilization and the organic treatment with bio-stabilized MSW amendment. For the clay soil, similar results were obtained. Significant differences were observed for the number of seeds per plant and the seed yield. These two parameters were significantly affected by the organic treatment with the bio-stabilized MSW amendment with respect to the control, but no differences were observed between the organic treatment with bio-stabilized MSW amendment and the mineral fertilization. Cucci et al. [26] reported similar findings for the faba bean mineral and organic fertilization to the results obtained in our research, where organic and mineral fertilization exhibited a similar number of pods per plant, and seeds per pod, thus not presenting significant differences. In another study with different rates of the bio-stabilized product of compost on faba bean plants, it was seen that there were no significant differences in the number of pods per plant, seeds per plant, and seeds per pod between treatments carried out in a sandy loam soil and clay loam soil for the cultivar variety Ryousaiissun [31]. In contrast, in the same study, for the cultivar Assiut 8, the soil type significantly affected the number of seeds per plant, which coincides with our findings showing significant differences for the type of fertilization. Faba bean yield components obtained in our study were in line with previous investigations regarding the number of seeds per pods [52,53], highlighting higher values depending on the genotype [54], number of pods per plant [31], reporting up to 12.5 pods per plant when applying the wet olive pomace organic amendment [30], and the number of seeds per plant [31]. Additionally, positive effects have been seen with phosphorous and zinc fertilization [51], as well as, spraying faba bean plants with a combination of iron, boron, and zinc fertilizer [55]. 
Table 3. Effect of organic (bio-stabilized MSW amendment) and mineral fertilization on faba bean seed yield and yield components in sandy soil and clay soil (mean $\pm \mathrm{SD}$ ).

\begin{tabular}{cccccc}
\hline Soil Type & Fertilization & $\begin{array}{c}\mathbf{N}^{\mathbf{o}} \\
\text { Pods/Plant }\end{array}$ & $\begin{array}{c}\mathbf{N}^{\mathbf{0}} \\
\text { Seeds/Plant }\end{array}$ & $\begin{array}{c}\mathbf{N}^{\mathbf{o}} \\
\text { Seeds/Pod }\end{array}$ & $\begin{array}{c}\text { Seed Yield } \\
\text { (g/Plant) }\end{array}$ \\
\hline \multirow{2}{*}{ Sandy } & Control & $2.67 \pm 2.89 \mathrm{a}$ & $6.33 \pm 4.93 \mathrm{a}$ & $2.52 \pm 1.19 \mathrm{a}$ & $2.385 \pm 1.92 \mathrm{a}$ \\
& Mineral & $3.67 \pm 0.58 \mathrm{a}$ & $10 \pm 2.00 \mathrm{ab}$ & $3.00 \pm 1.00 \mathrm{a}$ & $3.90 \pm 0.92 \mathrm{ab}$ \\
& Organic & $6.33 \pm 2.08 \mathrm{a}$ & $14.33 \pm 3.06 \mathrm{~b}$ & $2.72 \pm 0.25 \mathrm{a}$ & $4.37 \pm 1.76 \mathrm{~b}$ \\
Clay & Control & $4.67 \pm 1.53 \mathrm{a}$ & $12.67 \pm 4.93 \mathrm{a}$ & $2.67 \pm 0.34 \mathrm{a}$ & $3.60 \pm 2.30 \mathrm{a}$ \\
& Mineral & $6.67 \pm 2.08 \mathrm{a}$ & $13.00 \pm 4.58 \mathrm{ab}$ & $2.20 \pm 0.67 \mathrm{a}$ & $4.04 \pm 1.47 \mathrm{ab}$ \\
& Organic & $6.00 \pm 2.65 \mathrm{a}$ & $18.67 \pm 4.62 \mathrm{~b}$ & $3.29 \pm 0.89 \mathrm{a}$ & $6.59 \pm 0.57 \mathrm{~b}$ \\
\hline
\end{tabular}

Mean values with different letters in the same row vary significantly $(p<0.05$, Tukey HSD test).

\subsection{Faba Bean Nutritional Status}

Statistically significant effects were observed for fertilization in seed nitrogen and protein content (Table 4). Fertilized seeds showed higher nitrogen and protein content than the control in both soils. Higher nitrogen and protein content in faba bean seeds with fertilization were expected and in agreement with other investigations [56]. Contrary to previous results, which detected the highest protein content in faba bean seeds with mineral fertilization [30], the highest values in nitrogen and protein content were found in the organic treatment with the bio-stabilized MSW amendment and the clay soil, which was $3.71 \%$ higher for nitrogen content and $23.17 \%$ for protein content. The differences with the mineral treatment in both soils were small and not statistically significant, meaning that both types of fertilization can achieve the objective of increasing the nitrogen and protein content in the seeds, which are desired qualities in order to make faba bean more valuable for human consumption and animal consumption as feed [56]. With regards to nutrient accumulation in faba bean seeds, fertilization had no significant effects on the nutrients analyzed, with the exception of $\mathrm{Mn}$ and $\mathrm{Zn}$ (Table 4). The micronutrients $\mathrm{Mn}$ and $\mathrm{Zn}$ presented significant differences between the control and the fertilized treatments. This significant accumulation of $\mathrm{Mn}$ and $\mathrm{Zn}$ in faba bean seeds was achieved due to the high content of these micronutrients in the bio-stabilized MSW amendment. Additionally, by applying organic sources of $\mathrm{Mn}$ and $\mathrm{Zn}$, high biomass production can be obtained in cultivars [57]. In particular, these micronutrients have been found to enhance bean crop's biomass production and yield components [58], which can also explain the higher biomass production obtained in the organic treatments in this study.

Table 4. Effect of organic (bio-stabilized MSW amendment) and mineral fertilization on faba bean seed nitrogen, protein, and seed nutrient accumulation in sandy soil and clay soil (mean $\pm \mathrm{SD}$ ).

\begin{tabular}{ccccccc}
\hline \multirow{2}{*}{ Treatments } & \multicolumn{3}{c}{ Sandy } & \multicolumn{2}{c}{ Clay } \\
\cline { 2 - 7 } & Control & Mineral & Organic & Control & Mineral & Organic \\
\hline Nitrogen $(\%)$ & $3.25 \pm 0.24 \mathrm{a}$ & $3.64 \pm 0.21 \mathrm{~b}$ & $3.66 \pm 0.19 \mathrm{~b}$ & $3.36 \pm 0.06 \mathrm{a}$ & $3.54 \pm 0.12 \mathrm{~b}$ & $3.71 \pm 0.21 \mathrm{~b}$ \\
Protein $(\%)$ & $20.34 \pm 1.50 \mathrm{a}$ & $22.73 \pm 1.30 \mathrm{~b}$ & $22.88 \pm 1.17 \mathrm{~b}$ & $21.02 \pm 0.35 \mathrm{a}$ & $22.12 \pm 0.74 \mathrm{~b}$ & $23.17 \pm 1.29 \mathrm{~b}$ \\
$\mathrm{Ca}(\mathrm{mg} / \mathrm{kg})$ & $1052.2 \pm 49.6 \mathrm{a}$ & $945.2 \pm 139.9 \mathrm{a}$ & $958.1 \pm 70.1 \mathrm{a}$ & $957.0 \pm 37.8 \mathrm{a}$ & $983.6 \pm 91.7 \mathrm{a}$ & $1025.2 \pm 113.7 \mathrm{a}$ \\
$\mathrm{P}(\mathrm{mg} / \mathrm{kg})$ & $3463 \pm 314 \mathrm{a}$ & $4710 \pm 856 \mathrm{a}$ & $2895 \pm 758 \mathrm{a}$ & $3539 \pm 548 \mathrm{a}$ & $3206 \pm 171 \mathrm{a}$ & $3334 \pm 348 \mathrm{a}$ \\
$\mathrm{K}(\mathrm{mg} / \mathrm{kg})$ & $11,558 \pm 735 \mathrm{a}$ & $12,897 \pm 899 \mathrm{a}$ & $11,367 \pm 511 \mathrm{a}$ & $13,141 \pm 446 \mathrm{a}$ & $12,357 \pm 893 \mathrm{a}$ & $12,824 \pm 355 \mathrm{a}$ \\
$\mathrm{Mn}(\mathrm{mg} / \mathrm{kg})$ & $1.77 \pm 0.54 \mathrm{a}$ & $2.07 \pm 1.67 \mathrm{~b}$ & $3.93 \pm 1.53 \mathrm{~b}$ & $1.60 \pm 1.04 \mathrm{a}$ & $2.30 \pm 0.50 \mathrm{~b}$ & $3.43 \pm 0.45 \mathrm{~b}$ \\
$\mathrm{Fe}(\mathrm{mg} / \mathrm{kg})$ & $54.53 \pm 3.58 \mathrm{a}$ & $50.80 \pm 2.69 \mathrm{a}$ & $56.77 \pm 2.66 \mathrm{a}$ & $75.43 \pm 1.62 \mathrm{a}$ & $79.47 \pm 7.53 \mathrm{a}$ & $61.63 \pm 4.92 \mathrm{a}$ \\
$\mathrm{Mg}(\mathrm{mg} / \mathrm{kg})$ & $976.2 \pm 30.2 \mathrm{a}$ & $1042.8 \pm 93.2 \mathrm{a}$ & $947.1 \pm 49.0 \mathrm{a}$ & $1062.6 \pm 87.7 \mathrm{a}$ & $1034.1 \pm 37.4 \mathrm{a}$ & $1073.8 \pm 8.2 \mathrm{a}$ \\
$\mathrm{Zn}(\mathrm{mg} / \mathrm{kg})$ & $22.07 \pm 2.34 \mathrm{a}$ & $28.9 \pm 4.42 \mathrm{ab}$ & $35.70 \pm 5.31 \mathrm{~b}$ & $15.13 \pm 1.07 \mathrm{a}$ & $15.23 \pm 0.87 \mathrm{ab}$ & $16.47 \pm 1.44 \mathrm{~b}$ \\
$\mathrm{Cu}(\mathrm{mg} / \mathrm{kg})$ & $8.53 \pm 0.45 \mathrm{a}$ & $10.13 \pm 2.62 \mathrm{a}$ & $9.56 \pm 1.79 \mathrm{a}$ & $14.57 \pm 3.5 \mathrm{a}$ & $14.80 \pm 3.23 \mathrm{a}$ & $16.93 \pm 3.59 \mathrm{a}$ \\
\hline
\end{tabular}

Mean values with different letters in the same row vary significantly $(p<0.05$, Tukey HSD test).

The measurement of chlorophyll, flavonols, and anthocyanins in leaves also provided information regarding the effect of the environment on the faba bean plants (Figure 2). Leaf nutrient content is affected by fertilization and is expressed by leaf pigment contents $[59,60]$. 
Regarding the chlorophyll content throughout the treatments, higher values for chlorophyll were detected for fertilized treatments with respect to the control, which enhanced photosynthetic activities and increased faba bean biomass production [31]. This is explained because chlorophyll synthesis is enhanced by providing micronutrients, such as $\mathrm{Fe}, \mathrm{Mn}$, and $\mathrm{Zn}$, through fertilization [61], and the omission of these micronutrients can reduce the formation of chlorophyll rings [62]. The opposite effect was observed with flavonols and anthocyanins. These pigments appear under various biotic and abiotic stresses [63], which may explain the higher values obtained in the control treatments without fertilization.
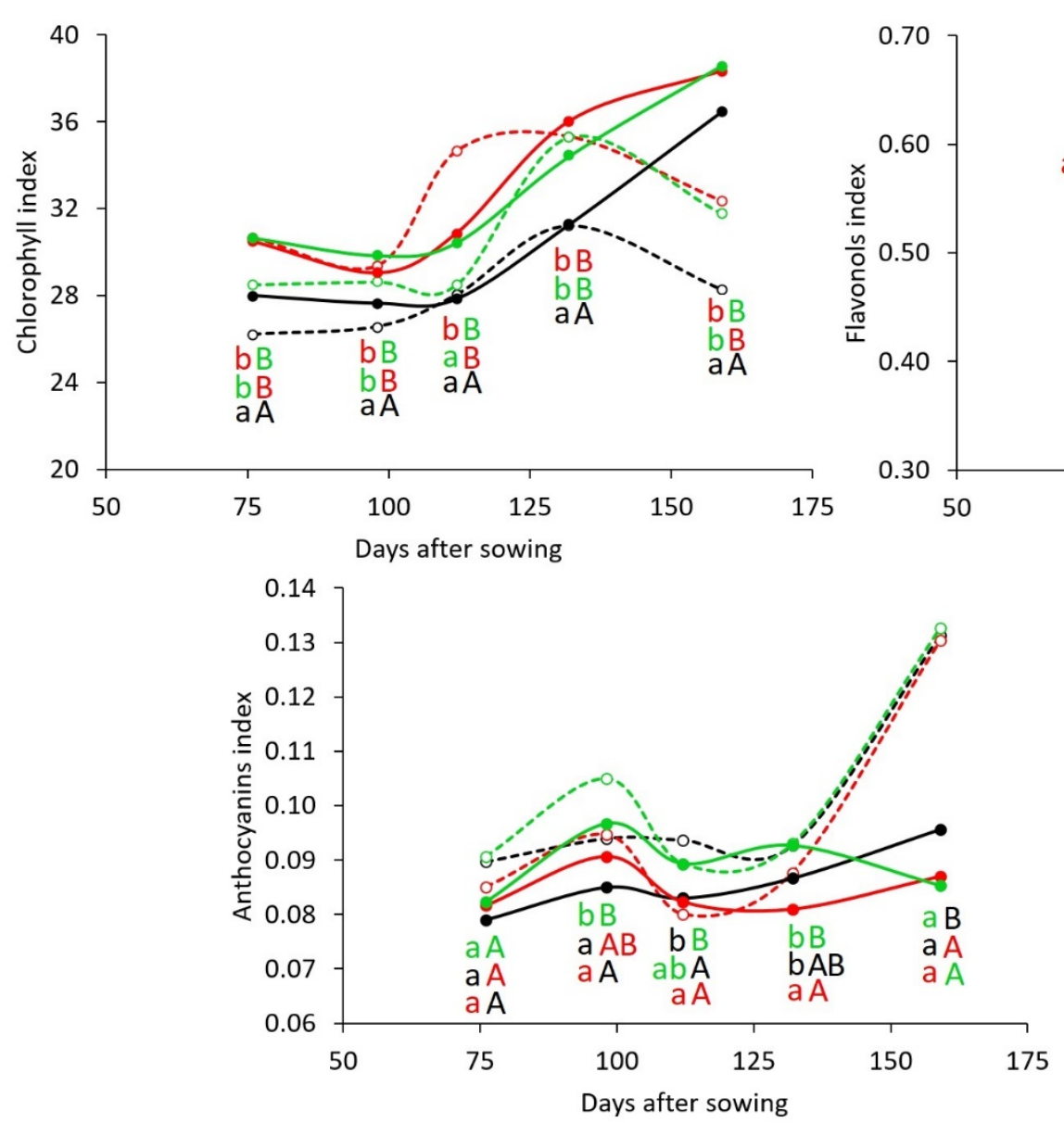

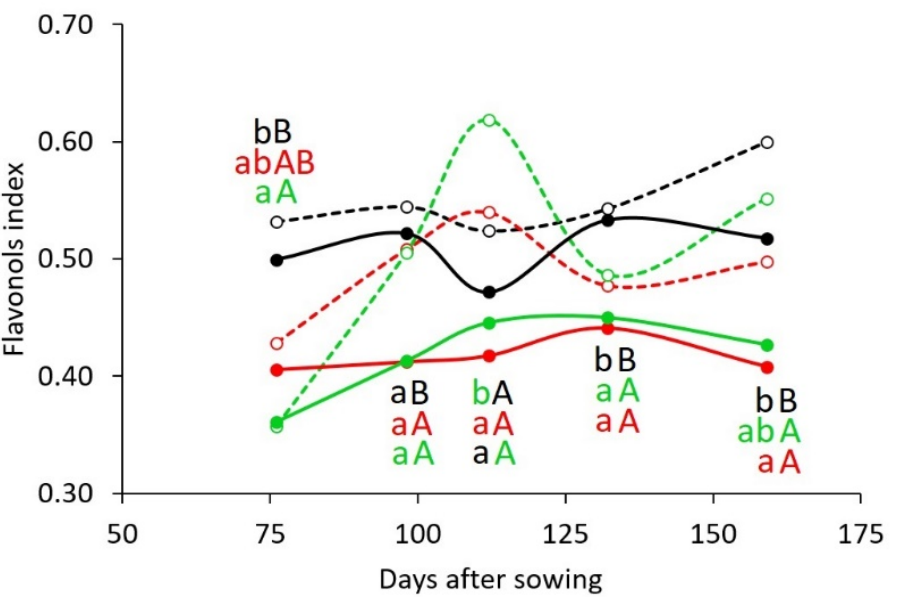

--o- Control (sandy soil)

--o- Mineral (sandy soil)

--o- Organic (sandy soil)

$\longrightarrow$ Control (clay soil)

$\rightarrow$ Mineral (clay soil)

$\longrightarrow$ Organic (clay soil)

Figure 2. Effect of organic (bio-stabilized MSW amendment), mineral fertilization and soil on faba bean chlorophyll, flavonols and anthocyanins content. Different letters at each date indicate significant differences according to the Tukey HSD test at $p \leq 0.05$, lower case letters define sandy soil and capital letters define clay soil.

\subsection{Soil Fertility}

Regarding soil properties, results showed that the soil $\mathrm{pH}$ was significantly affected by fertilization (Table 5). In contrast with other investigations resulting in soil acidification after organic amendments [64], our findings showed a $\mathrm{pH}$ increase due to organic fertilization by the bio-stabilized MSW amendment [65]. A possible explanation is the addition of basic cations with the organic amendments [66], and other chemical mechanisms occurring in the soil [67]. It must be noted that the soil nature can affect the resulting $\mathrm{pH}$ after organic fertilization. Melero et al. [68] observed a slight increase in the soil $\mathrm{pH}$ due to organic fertilization, similar to our case. In the case of Melero et al. [68], the high carbonate content in the soil presented a high buffering capacity resulting in a maximum $\mathrm{pH}$ increase of $3 \%$. In our research, the increase in $\mathrm{pH}$ with the bio-stabilized MSW amendment addition was slightly lower in the clay soil than in the sandy soil with respect to the control, being a $3 \%$ increase for clay soil and a $4 \%$ increase for sandy soil. This is due to the higher buffering 
capacity of soils with clay content, which increases the resistance to $\mathrm{pH}$ changes [69]. Nevertheless, the soil $\mathrm{pH}$ of the control and fertilized treatments were within the $\mathrm{pH}$ range of 6.5-9 to achieve the best production of faba bean [70]. Values of the E.C. were the same for both soils and fertilization, mineral and organic, and were significantly higher than the control. The increase in E.C. was also reported in other organic amendment investigations attributing the E.C. increase to the number of dissolved salts in organic fertilizers [67]. As expected, in both soils, organic fertilization exhibited the highest increase in organic carbon. The addition of bio-stabilized fertilizers increases soils' organic matter content and favors organic carbon sequestration [68,71].

Table 5. Effect of organic (bio-stabilized MSW amendment) and mineral fertilization on sandy soil and clay soil physicochemical properties, soil nutrients, and heavy metals (mean \pm SD).

\begin{tabular}{|c|c|c|c|c|c|c|}
\hline \multirow{2}{*}{ Treatments } & \multicolumn{3}{|c|}{ Sandy } & \multicolumn{3}{|c|}{ Clay } \\
\hline & Control & Mineral & Organic & Control & Mineral & Organic \\
\hline $\mathrm{pH}$ & $7.71 \pm 0.01 \mathrm{a}$ & $7.91 \pm 0.1 \mathrm{~b}$ & $8.03 \pm 0.03 c$ & $7.82 \pm 0.02 \mathrm{a}$ & $7.91 \pm 0.01 b$ & $8.06 \pm 0.05 c$ \\
\hline E.C. $(\mathrm{dS} / \mathrm{m})$ & $0.07 \pm 0.01 \mathrm{a}$ & $0.11 \pm 0.01 b$ & $0.11 \pm 0.01 b$ & $0.09 \pm 0.02 \mathrm{a}$ & $0.11 \pm 0.01 b$ & $0.11 \pm 0.01 b$ \\
\hline Organic carbon (\%) & $0.67 \pm 0.03 \mathrm{a}$ & $0.69 \pm 0.01 \mathrm{a}$ & $0.72 \pm 0.02 b$ & $0.67 \pm 0.012 \mathrm{a}$ & $0.69 \pm 0.02 \mathrm{a}$ & $0.73 \pm 0.02 b$ \\
\hline Kjeldahl N (\%) & $0.08 \pm 0.01 \mathrm{a}$ & $0.09 \pm 0.01 b$ & $0.10 \pm 0.01 b$ & $0.07 \pm 0.01 \mathrm{a}$ & $0.09 \pm 0.01 b$ & $0.10 \pm 0.02 b$ \\
\hline $\mathrm{K} 2 \mathrm{O}(\%)$ & $0.51 \pm 0.01 \mathrm{a}$ & $0.43 \pm 0.04 b$ & $0.61 \pm 0.01 \mathrm{c}$ & $0.45 \pm 0.02 \mathrm{a}$ & $0.47 \pm 0.02 \mathrm{~b}$ & $0.53 \pm 0.03 c$ \\
\hline P2O5 (\%) & $0.06 \pm 0.02 \mathrm{a}$ & $0.08 \pm 0.01 b$ & $0.09 \pm 0.01 b$ & $0.05 \pm 0.01 \mathrm{a}$ & $0.07 \pm 0.01 \mathrm{~b}$ & $0.07 \pm 0.01 \mathrm{~b}$ \\
\hline $\mathrm{CaO}(\%)$ & $3.10 \pm 0.01 \mathrm{a}$ & $3.60 \pm 0.01 b$ & $3.69 \pm 0.01 c$ & $3.58 \pm 0.01 \mathrm{a}$ & $3.61 \pm 0.01 b$ & $3.73 \pm 0.02 c$ \\
\hline $\mathrm{MgO}(\%)$ & $0.35 \pm 0.02 \mathrm{a}$ & $0.41 \pm 0.02 \mathrm{~b}$ & $0.44 \pm 0.01 \mathrm{~b}$ & $0.35 \pm 0.01 \mathrm{a}$ & $0.42 \pm 0.03 b$ & $0.41 \pm 0.05 b$ \\
\hline $\mathrm{Zn}(\mathrm{mg} / \mathrm{kg})$ & $15.77 \pm 2.85 \mathrm{a}$ & $28.33 \pm 0.57 b$ & $35.57 \pm 1.20 \mathrm{c}$ & $19.36 \pm 0.47 \mathrm{a}$ & $27.10 \pm 1.71 b$ & $36.53 \pm 1.55 c$ \\
\hline $\mathrm{Cu}(\mathrm{mg} / \mathrm{kg})$ & $18.63 \pm 1.04 \mathrm{a}$ & $23.10 \pm 0.72 b$ & $32.4 \pm 1.01 \mathrm{c}$ & $16.90 \pm 2.08 \mathrm{a}$ & $22.73 \pm 0.58 b$ & $30.13 \pm 2.83 c$ \\
\hline $\mathrm{Cr}(\mathrm{mg} / \mathrm{kg})$ & $5.41 \pm 0.17 \mathrm{a}$ & $16.58 \pm 1.76 b$ & $21.43 \pm 1.32 c$ & $7.26 \pm 0.59 \mathrm{a}$ & $12.97 \pm 1.55 b$ & $24.93 \pm 0.21 c$ \\
\hline $\mathrm{Ni}(\mathrm{mg} / \mathrm{kg})$ & $4.85 \pm 0.04 \mathrm{a}$ & $5.96 \pm 0.8 \mathrm{~b}$ & $16.30 \pm 0.30 c$ & $4.68 \pm 0.17 \mathrm{a}$ & $5.76 \pm 0.28 b$ & $16.49 \pm 0.70 c$ \\
\hline $\mathrm{Pb}, \mathrm{Cd}(\mathrm{mg} / \mathrm{kg})$ & $<0.2 \pm 0.01 \mathrm{a}$ & $<0.2 \pm 0.01 \mathrm{a}$ & $<0.2 \pm 0.01 \mathrm{a}$ & $<0.2 \pm 0.01 \mathrm{a}$ & $<0.2 \pm 0.01 \mathrm{a}$ & $<0.2 \pm 0.01 \mathrm{a}$ \\
\hline
\end{tabular}

Mean values with different letters in the same row vary significantly $(p<0.05$, Tukey HSD test).

The soil organic carbon was significantly increased in the organic treatment, presenting approximately $4 \%$ more soil organic carbon in the organic treatment than in the mineral treatment in both soils. Regarding Kjeldahl N, differences were significant between the fertilized treatments with respect to the control, meaning that the organic treatments achieved similar nitrogen content in both soils compared with the mineral treatment. The organic treatment with bio-stabilized MSW amendment presented the highest content of nutrients for both soils, the increase in sandy soil with respect to control was 19, 50,19, and $25 \%$, and in the clay soil $15,40,4$, and $17 \%$, for $\mathrm{K}_{2} \mathrm{O}, \mathrm{P}_{2} \mathrm{O}_{5}, \mathrm{CaO}$, and $\mathrm{MgO}$, respectively. An increase in the nutrient values was expected, as bio-stabilized amendments applications supply these nutrients into the soil [72,73]. Regarding the type of soil, a significant influence was observed in $\mathrm{K}_{2} \mathrm{O}$ and $\mathrm{CaO}$. Higher clay content in soils favors the adsorption of nutrients. However, the lower values of $\mathrm{K}_{2} \mathrm{O}$ in the clay soil with respect to the sandy soil can be due to nutrient fixation presenting a low capacity to return them to the soil [68].

An important aspect to consider in organic fertilization is the addition of heavy metals to the soils. A significant effect was observed in the different fertilization treatments. For all the heavy metals and in both types of soils, the organic treatment exhibited the highest values. The bio-stabilized MSW amendment contained heavy metals, such as $\mathrm{Zn}, \mathrm{Cu}, \mathrm{Cr}$, $\mathrm{Ni}, \mathrm{Pb}$, and $\mathrm{Cd}$, so it was expected that both soils amended with this organic fertilizer presented the highest content of heavy metals. The increase in sandy soil with respect to the mineral treatment was $25,40,29$, and $173 \%$, and in the clay soil of $34,32,92$, and $186 \%$, for $\mathrm{Zn}, \mathrm{Cu}, \mathrm{Cr}$, and $\mathrm{Ni}$, respectively. Heavy metals in soils can cause detrimental effects on the environment. For that reason, the concentration of heavy metals in soils for the application of bio-stabilized amendments is regulated by the Spanish government establishing heavy metal limits [74]. In our case, the concentrations of heavy metals obtained in the organic fertilization treatment for both soils were below the regulated limits, making this biostabilized MSW amendment a viable organic fertilizer. Besides agricultural purposes, 
organic fertilizers, such as those studied in this research, can be used on marginal land. Marginal land has nutrient-poor and undesirable soil characteristics for profitable crops. Valorization of MSW can be carried out by applying the bio-stabilized MSW amendment on this soil to improve soil's nutrient content and chemical characteristics as observed in the application of other organic fertilizers [75].

\subsection{Nematode Community}

Twelve nematode taxa appeared in the experimental samples. Five of them were bacterivores, while three taxa were fungivores, two were herbivores, and two were omnivores (Table 6). No predators were found. The most abundant taxa in the clay soil were the bacterivore Acrobeloides and the fungivore Aphelenchus, while only Aphelenchus clearly dominated in sandy soil. Eight nematodes taxa were significantly affected by soil type, all of them (except Eudorylaimus) being more abundant in the clay soil than in the sandy soil. The fungivore Aphelenchus was more abundant in the organic treatment than in the other two treatments irrespectively of the soil type (Table 6). The effect of the interaction Soil x Treatment significantly affected the abundance of Acrobeloides, with the highest abundances in the organic treatment with the bio-stabilized MSW amendment in the clay soil and lowest in the non-amended control, and a similar pattern was found for Aphelenchus (Table 6). The omnivore Eudorylaimus was the only nematode showing the opposite pattern, with high abundances in the non-amended control and low in the organic treatment in clay soil. The total nematode abundances were affected by soil type and soil treatments, and were in general high, with average abundances ranging between 517-7989 nematodes/100 g of dry soil (Table 6). The nematode analysis in this study determined that nematode abundances were quite large compared with typical values in semiarid areas [76]. In agreement with previous studies, no negative effects of mineral and organic fertilization on total nematode abundances were detected [77]. Indeed, the addition of this bio-stabilized MSW amendment clearly stimulated the abundance of the nematode community, inducing relevant changes in its structure. Although both sandy and clay soils presented similar properties, the positive effects of soil fertilization on the total nematode abundance were particularly evident in the sandy soils, since the sandy control pots were found to present much lower nematode abundances than the other soil treatments, probably resulting from low resources availability.

The contribution of bacterivores to the nematode community was significantly higher in the clay soil than in the sandy one (Figure 3) and was highest in the organic treatment in the clay soil and lowest in all sandy soils, respectively (Figure 3). The interaction soil $\times$ treatment marginally affected the soil fungivores $(p=0.05)$, with high abundances in amended sandy soils. The soil type also affected the proportion of herbivores and omnivores, which presented higher relative abundances in the clay and sandy soils, respectively (Figure 3). The increased abundances of generalist fungivore nematodes in the soils fertilized with the bio-stabilized MSW amendment in the sandy soil trials, with almost three times more fungivores than the unamended soils and a strong reduction in bacterivores, indicated increased availability of fungal populations in the soil. In this soil, mineral and organic fertilization strongly reduced the complexity of the nematode community, as has been reported in previous field experiments [78]. In clay soils, however, the addition of bio-stabilized MSW amendment induced an increase in bacterivores, a pattern previously detected [79], and a reduction in fungivores. 
Table 6. Number of nematodes (mean \pm SD) per $100 \mathrm{~g}$ of dry soil in two types of soil and three soil treatments (control, mineral, and organic (bio-stabilized MSW amendment)). Trophic (Ba: bacterivores, Fu: fungivores, Herb: herbivores, On: omnivores) and c-p groups are shown. The $F$-values and the significance of the effects $\left(* * * p<0.01 ;{ }^{* *} p<0.05\right)$ of type of soil and soil treatments are indicated.

\begin{tabular}{|c|c|c|c|c|c|c|c|c|c|c|c|c|c|c|}
\hline \multirow[t]{2}{*}{ Taxa } & \multirow[t]{2}{*}{ TG } & \multirow[t]{2}{*}{$\mathrm{C}-\mathrm{P}$} & \multicolumn{3}{|c|}{ Clay } & \multicolumn{3}{|c|}{ Sand } & \multicolumn{2}{|c|}{ Soil } & \multicolumn{2}{|c|}{ Treat } & \multicolumn{2}{|c|}{ Soil x Treat } \\
\hline & & & Control & Mineral & Organic & Control & Mineral & Organic & $F$ & $p$ & $F$ & $p$ & $F$ & $p$ \\
\hline Panagrolaimus & $\mathrm{Ba}$ & 1 & $\begin{array}{c}0.00 \\
\pm 0.00\end{array}$ & $\begin{array}{c}0.00 \\
\pm 0.00\end{array}$ & $\begin{array}{c}0.00 \\
\pm 0.00\end{array}$ & $\begin{array}{c}0.00 \\
\pm 0.00\end{array}$ & $\begin{array}{c}0.00 \\
\pm 0.00\end{array}$ & $\begin{array}{c}8.28 \\
\pm 14.33\end{array}$ & & & & & & \\
\hline Acrobeles & $\mathrm{Ba}$ & 2 & $\begin{array}{l}20.07 \\
\pm 17.80\end{array}$ & $\begin{array}{c}77.13 \\
\pm 79.63\end{array}$ & $\begin{array}{c}259.88 \\
\pm 294.11\end{array}$ & $\begin{array}{c}14.58 \\
\pm 14.29\end{array}$ & $\begin{array}{c}0.00 \\
\pm 0.00\end{array}$ & $\begin{array}{c}0.00 \\
\pm 0.00\end{array}$ & 13.63 & $* * *$ & & & & \\
\hline Acrobeloides & $\mathrm{Ba}$ & 2 & $\begin{array}{l}1307.08 \\
\pm 325.16\end{array}$ & $\begin{array}{c}876.07 \\
\pm 255.26\end{array}$ & $\begin{array}{c}4495.04 \\
\pm 3603.62\end{array}$ & $\begin{array}{c}83.49 \\
\pm 23.43\end{array}$ & $\begin{array}{l}177.17 \\
\pm 75.35\end{array}$ & $\begin{array}{l}75.36 \\
\pm 1.46\end{array}$ & 202.6 & $* * *$ & & & 11.32 & $* * *$ \\
\hline Heterocephalus & $\mathrm{Ba}$ & 2 & $\begin{array}{l}110.72 \\
\pm 56.35\end{array}$ & $\begin{array}{c}64.61 \\
\pm 39.41\end{array}$ & $\begin{array}{c}43.87 \\
\pm 41.68\end{array}$ & $\begin{array}{c}83.63 \\
\pm 75.16\end{array}$ & $\begin{array}{c}8.84 \\
\pm 8.13\end{array}$ & $\begin{array}{c}42.23 \\
\pm 39.05\end{array}$ & & & & & & \\
\hline Cervidellus & $\mathrm{Ba}$ & 2 & $\begin{array}{c}20.87 \\
\pm 18.27\end{array}$ & $\begin{array}{c}0.00 \\
\pm 0.00\end{array}$ & $\begin{array}{c}0.00 \\
\pm 0.00\end{array}$ & $\begin{array}{c}0.00 \\
\pm 0.00\end{array}$ & $\begin{array}{l}0.00 \\
\pm 0.00\end{array}$ & $\begin{array}{c}0.00 \\
\pm 0.00\end{array}$ & 3.99 & $* *$ & & & 3.99 & $* *$ \\
\hline Aphelenchus & $\mathrm{Fu}$ & 2 & $\begin{array}{r}1602.55 \\
\pm 413.58\end{array}$ & $\begin{array}{l}1347.42 \\
\pm 650.96\end{array}$ & $\begin{array}{l}2314.56 \\
\pm 150.57\end{array}$ & $\begin{array}{l}133.19 \\
\pm 37.04\end{array}$ & $\begin{array}{r}1059.61 \\
\pm 233.59\end{array}$ & $\begin{array}{c}2334.73 \\
\pm 1750.30\end{array}$ & 17.01 & $* * *$ & 13.08 & $* * *$ & 9.77 & $* * *$ \\
\hline Aphelenchoides & $\mathrm{Fu}$ & 2 & $\begin{array}{c}78.39 \\
\pm 32.40\end{array}$ & $\begin{array}{c}26.92 \\
\pm 46.63\end{array}$ & $\begin{array}{l}100.04 \\
\pm 18.62\end{array}$ & $\begin{array}{c}16.72 \\
\pm 28.96\end{array}$ & $\begin{array}{c}0.00 \\
\pm 0.00\end{array}$ & $\begin{array}{c}0.00 \\
\pm 0.00\end{array}$ & 20.95 & $* * *$ & & & & \\
\hline Tylenchidae & $\mathrm{Fu}$ & 2 & $\begin{array}{c}76.79 \\
\pm 25.10\end{array}$ & $\begin{array}{c}93.06 \\
\pm 24.66\end{array}$ & $\begin{array}{c}467.19 \\
\pm 738.54\end{array}$ & $\begin{array}{c}2.62 \\
\pm 2.28\end{array}$ & $\begin{array}{c}14.79 \\
\pm 14.23\end{array}$ & $\begin{array}{c}2.26 \\
\pm 3.91\end{array}$ & 12.57 & $* * *$ & & & & \\
\hline Tylenchorhynchus & Herb & 3 & $\begin{array}{c}193.29 \\
\pm 155.59\end{array}$ & $\begin{array}{c}300.56 \\
\pm 302.64\end{array}$ & $\begin{array}{c}262.27 \\
\pm 296.58\end{array}$ & $\begin{array}{c}6.17 \\
\pm 6.12\end{array}$ & $\begin{array}{c}0.00 \\
\pm 0.00\end{array}$ & $\begin{array}{c}4.52 \\
\pm 7.83\end{array}$ & 61.64 & $* * *$ & & & & \\
\hline Helicotylenchus & Herb & 3 & $\begin{array}{c}9.56 \\
\pm 16.56\end{array}$ & $\begin{array}{c}0.00 \\
\pm 0.00\end{array}$ & $\begin{array}{c}0.00 \\
\pm 0.00\end{array}$ & $\begin{array}{c}0.00 \\
\pm 0.00\end{array}$ & $\begin{array}{c}0.00 \\
\pm 0.00\end{array}$ & $\begin{array}{c}0.00 \\
\pm 0.00\end{array}$ & & & & & & \\
\hline Eudorylaimus & Omn & 4 & $\begin{array}{c}0.00 \\
\pm 0.00\end{array}$ & $\begin{array}{c}49.11 \\
\pm 22.92\end{array}$ & $\begin{array}{c}46.26 \\
\pm 48.83\end{array}$ & $\begin{array}{l}170.42 \\
\pm 89.74\end{array}$ & $\begin{array}{c}80.68 \\
\pm 88.79\end{array}$ & $\begin{array}{c}71.56 \\
\pm 31.68\end{array}$ & 7.99 & $* *$ & & & 5.34 & $* *$ \\
\hline Mesodorylaimus & Omn & 4 & $\begin{array}{l}0.00 \\
\pm 0.00\end{array}$ & $\begin{array}{c}0.00 \\
\pm 0.00\end{array}$ & $\begin{array}{c}0.00 \\
\pm 0.00\end{array}$ & $\begin{array}{c}6.27 \\
\pm 10.86\end{array}$ & $\begin{array}{c}0.00 \\
\pm 0.00\end{array}$ & $\begin{array}{c}0.00 \\
\pm 0.00\end{array}$ & & & & & & \\
\hline Total. $/ 100 \mathrm{~g} \mathrm{ds}$ & & & $\begin{array}{l}3419.32 \\
\pm 624.03\end{array}$ & $\begin{array}{l}2834.88 \\
\pm 961.94\end{array}$ & $\begin{array}{c}7989.11 \\
\pm 4925.29\end{array}$ & $\begin{array}{c}517.09 \\
\pm 158.40\end{array}$ & $\begin{array}{c}1341.10 \\
\pm 352.74\end{array}$ & $\begin{array}{c}2538.94 \\
\pm 1749.63\end{array}$ & 30.54 & $* * *$ & 7.04 & $* * *$ & & \\
\hline
\end{tabular}
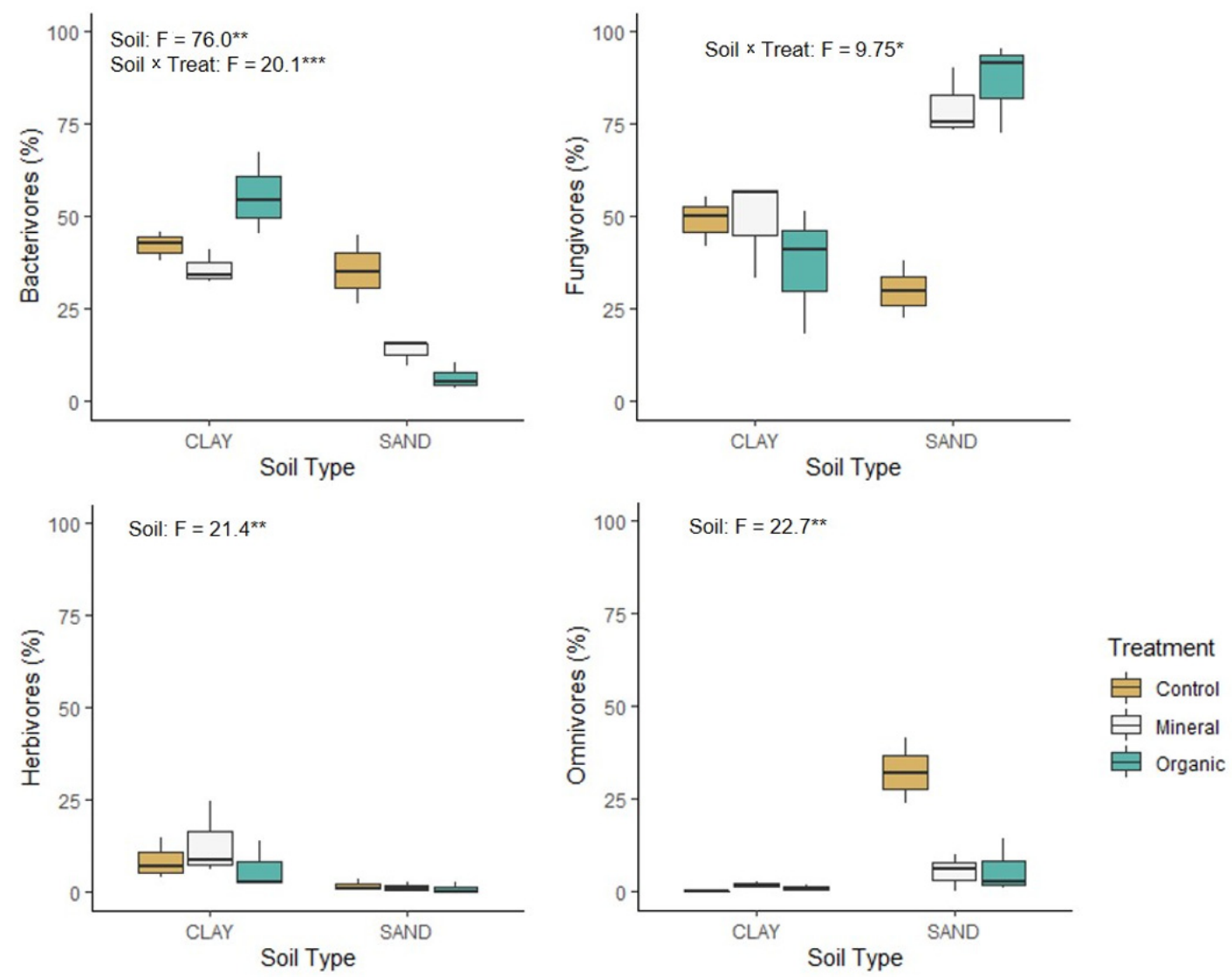

Figure 3. Boxplots of trophic group \% abundances across two soil types and three soil treatments. Boxplots show medians, lower quartile, and upper quartile values. $F$ values and significant effects are shown for soil type and treatments $\left({ }^{* * *} p<0.01\right.$; ** $\left.p<0.05 ;{ }^{*} p<0.1\right)$. 
The soil food web diagnosis showed that the Enrichment and Structure indices and footprints varied across soil types and were affected by the interaction soil $\times$ treatment (Table 7), although all soils fell within the disturbed category except non-amended sandy soils that were degraded (Figure 4). In clay soil, mineral fertilization increased the enrichment footprint, an indicator of the magnitude of ecosystem function performed by microbivore nematodes, but reduced the Enrichment Index, while the structure indicators were eliminated (Figure 3). In sandy soil, the non-amended treatment clearly differed from amended ones, with a low Enrichment Index and footprint but large structure ones (Figure 4).

Table 7. Values (mean $\pm \mathrm{SD}$ ) of the Structure Index (SI), the Enrichment Index (EI), the structure footprint (SF), and the enrichment footprint (EF) in two types of soil and three soil treatments (control, mineral and organic (bio-stabilized MSW amendment)). The $F$-values and the significance of the effects $\left(* * *<0.01 ;{ }^{* *} p<0.05\right)$ of type of soil and soil treatments are indicated.

\begin{tabular}{|c|c|c|c|c|c|c|c|c|c|c|c|c|}
\hline & \multicolumn{3}{|c|}{ Clay } & \multicolumn{3}{|c|}{ Sand } & \multicolumn{2}{|c|}{ Soil } & \multicolumn{2}{|c|}{ Treat } & \multicolumn{2}{|c|}{ Soil $x$ Treat } \\
\hline & Control & Mineral & Organic & Control & Mineral & Organic & $F$ & $p$ & $F$ & $p$ & $F$ & $p$ \\
\hline SI & $\begin{array}{c}0.00 \\
\pm 0.00\end{array}$ & $\begin{array}{c}7.73 \\
\pm 3.08\end{array}$ & $\begin{array}{c}3.46 \\
\pm 3.48\end{array}$ & $\begin{array}{l}65.58 \\
\pm 9.03\end{array}$ & $\begin{array}{c}17.47 \\
\pm 15.94\end{array}$ & $\begin{array}{c}18.22 \\
\pm 19.86\end{array}$ & 15.40 & $* * *$ & & & 6.46 & $* *$ \\
\hline EI & $\begin{array}{l}34.86 \\
\pm 2.12\end{array}$ & $\begin{array}{l}36.08 \\
\pm 4.50\end{array}$ & $\begin{array}{l}27.47 \\
\pm 8.81\end{array}$ & $\begin{array}{l}31.20 \\
\pm 5.09\end{array}$ & $\begin{array}{l}45.98 \\
\pm 1.29\end{array}$ & $\begin{array}{l}48.48 \\
\pm 1.64\end{array}$ & 9.56 & $* * *$ & & & 6.91 & $* *$ \\
\hline SF & $\begin{array}{c}0.00 \\
\pm 0.00\end{array}$ & $\begin{array}{c}35.03 \\
\pm 16.35\end{array}$ & $\begin{array}{c}33.00 \\
\pm 34.84\end{array}$ & $\begin{array}{c}123.88 \\
\pm 67.84\end{array}$ & $\begin{array}{c}57.56 \\
\pm 63.35\end{array}$ & $\begin{array}{c}51.05 \\
\pm 22.60\end{array}$ & 7.17 & $* *$ & & & 5.29 & $* *$ \\
\hline $\mathrm{EF}$ & $\begin{array}{l}169.69 \\
\pm 40.61\end{array}$ & $\begin{array}{l}139.89 \\
\pm 64.89\end{array}$ & $\begin{array}{l}244.14 \\
\pm 15.61\end{array}$ & $\begin{array}{l}14.83 \\
\pm 2.98\end{array}$ & $\begin{array}{l}108.50 \\
\pm 23.92\end{array}$ & $\begin{array}{c}241.12 \\
\pm 179.51\end{array}$ & 16.96 & $* * *$ & 12.31 & $* * *$ & 9.11 & $* * *$ \\
\hline
\end{tabular}

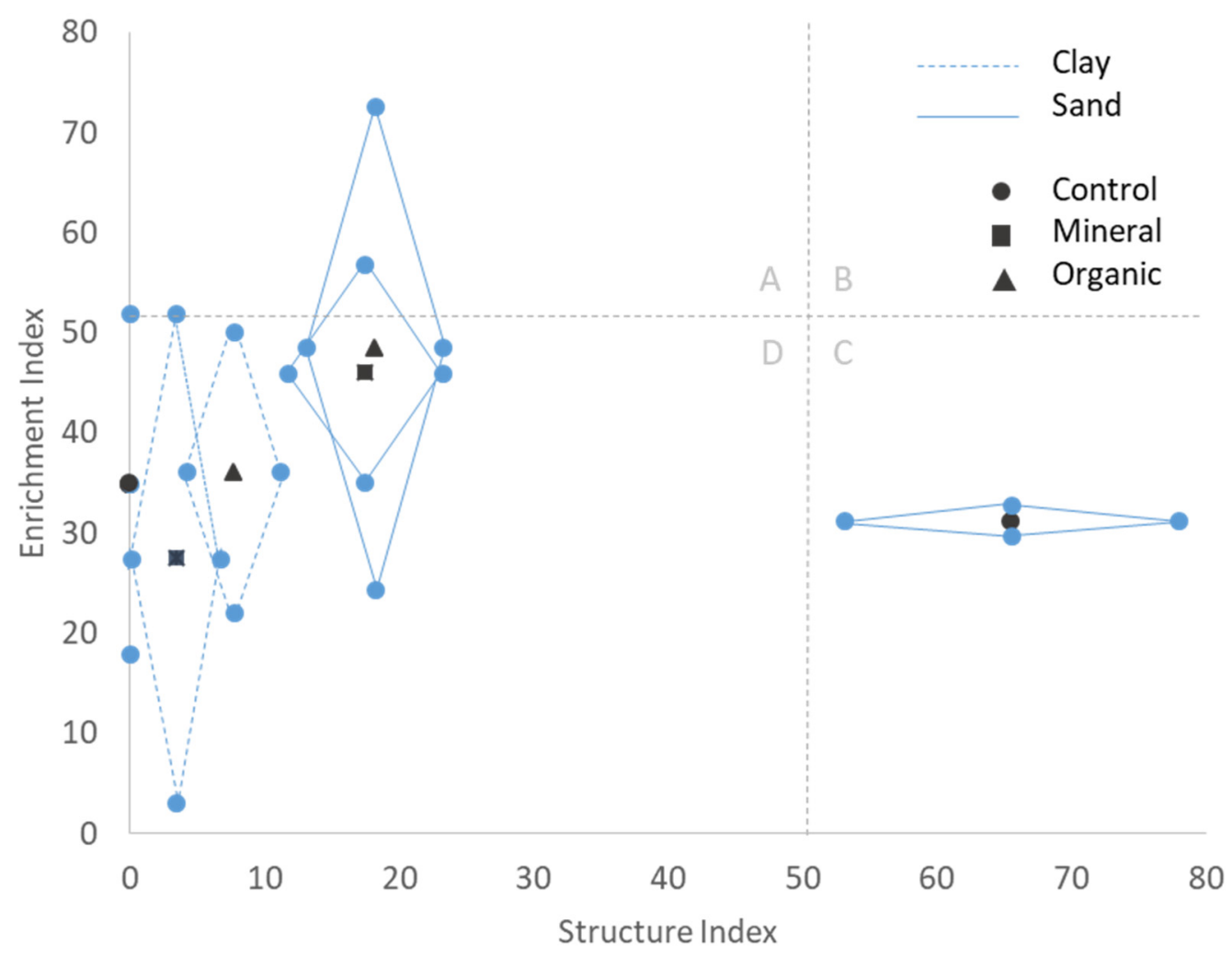

Figure 4. Soil food web diagnosis of different soil treatments based on SI and EI values (centroids of the rhomboids) and comparison of the Structure and Enrichment footprints (rhombus sizes at both axes) in both types of soil. 


\section{Conclusions}

This research aimed to evaluate the valorization of a bio-stabilized MSW amendment for the production of the faba bean crop. The valorization of this organic amendment reduces solid waste accumulation in the environment, and provides a source of organic agricultural fertilizer. Results obtained in this study revealed the potential use of the biostabilized MSW amendment to achieve the same faba bean biomass production, growth, and seed yield as with mineral fertilization in the sandy and clay soils. In addition, the application of the bio-stabilized MSW amendment was found to significantly increase the seed quality in terms of nitrogen and protein content, and favor $\mathrm{Mn}$ and $\mathrm{Zn}$ accumulation in seeds. Moreover, the application of this bio-stabilized MSW amendment showed positive effects on soil properties. The findings from this investigation showed that the organic fertilization with the bio-stabilized MSW amendment was more effective than the mineral fertilization in increasing soil's organic carbon, and achieved the same nitrogen content for sandy and clay soils as the mineral treatments. As heavy metals accumulation in the bio-stabilized MSW amendment treatments did not exceed the regulated limits, results indicate it can be used in short-term fertilizations. Additionally, to improve faba bean and soil properties, the bio-stabilized MSW amendment improved the nematode community. This organic fertilizer increased the enrichment footprint in both types of soil, sandy and clay soils, while the application of mineral fertilizers only enhanced such function in sandy soils. This study highlighted the potential use of the bio-stabilized MSW amendment as organic fertilizer for agriculture, such as faba bean cultivation, as an alternative to the use of chemical fertilizers. Substituting or combining mineral fertilizers with organic fertilizers, such as this bio-stabilized MSW amendment, promotes a circular economy, and a more environmentally sustainable fertilization, while guaranteeing food security.

Author Contributions: Conceptualization, S.M., S.S.-M., J.L.G., C.Á., M.d.M.D.; methodology, M.d.M.D., C.Á. and S.S.-M.; software, S.M.; validation, J.L.G.; formal analysis, S.M. and S.S.-M.; investigation, M.d.M.D. and S.S.-M.; resources, M.d.M.D., J.L.G., and C.Á.; data curation, S.M., J.L.G., M.d.M.D. and S.S.-M.; writing—original draft preparation, S.M., and S.S.-M.; writing-review and editing, J.L.G., S.M. and M.d.M.D.; visualization, S.M., M.d.M.D. and J.L.G.; supervision, M.d.M.D.; project administration, M.d.M.D. and C.Á.; funding acquisition, M.d.M.D. and J.L.G. All authors have read and agreed to the published version of the manuscript.

Funding: This research was funded by the company URBASER S.A, CAM (AGRISOST-CM S2018/BAA4330 project) and Structural Funds 2014-2020 (ERDF y ESF).

Institutional Review Board Statement: Not applicable.

Data Availability Statement: The study did not report any additional data.

Conflicts of Interest: The authors declare no conflict of interest.

\section{References}

1. Kaza, S.; Yao, L.C.; Bhada-Tata, P.; Van Woerden, F. What a Waste 2.0: A Global Snapshot of Solid Waste Management to 2050. Urban Development; World Bank: Washington, DC, USA, 2018. Available online: https://openknowledge.worldbank.org/handle/1098 6/30317 (accessed on 4 June 2019).

2. Chen, T.; Zhang, S.; Yuan, Z. Adoption of solid organic waste composting products: A critical review. J. Clean. Prod. 2020, 272, 122712. [CrossRef]

3. Tenodi, S.; Krčmar, D.; Agbaba, J.; Zrnić, K.; Radenović, M.; Ubavin, D.; Dalmacija, B. Assessment of the environmental impact of sanitary and unsanitary parts of a municipal solid waste landfill. J. Environ. Manag. 2020, 258, 110019. [CrossRef] [PubMed]

4. Cudjoe, D.; Acquah, P.M. Environmental impact analysis of municipal solid waste incineration in African countries. Chemosphere 2021, 265, 129186. [CrossRef] [PubMed]

5. Sharma, B.; Vaish, B.; Srivastava, V.; Singh, S.; Singh, P.; Singh, R.P. An Insight to Atmospheric Pollution-Improper Waste Management and Climate Change Nexus; Springer: Berlin/Heidelberg, Germany, 2018.

6. Sauve, G.; Van Acker, K. The environmental impacts of municipal solid waste landfills in Europe: A life cycle assessment of proper reference cases to support decision making. J. Environ. Manag. 2020, 261, 110216. [CrossRef]

7. Tognetti, C.; Mazzarino, M.J.; Laos, F. Compost of municipal organic waste: Effects of different management practices on degradability and nutrient release capacity. Soil Biol. Biochem. 2008, 40, 2290-2296. [CrossRef] 
8. Saveyn, H.; Eder, P. End-of-Waste Criteria for Biodegradable Waste Subjected to Biological Treatment (Compost E Digestate): Technical Proposals; Publications Office of the European Union: Luxembourg, 2013. [CrossRef]

9. Jara-Samaniego, J.; Pérez-Murcia, M.D.; Bustamante, M.A.; Pérez-Espinosa, A.; Paredes, C.; López, M.; López-Lluch, D.B.; Gavilanes-Terán, I.; Moral, R. Composting as sustainable strategy for municipal solid waste management in the Chimborazo Region, Ecuador: Suitability of the obtained composts for seedling production. J. Clean Prod. 2017, 141, 1349-1358. [CrossRef]

10. Míguez, F.; Gómez-Sagasti, M.T.; Hernández, A.; Artetxe, U.; Blanco, F.; Castañeda, J.H.; Lozano, J.V.; Garbisu, C.; Becerril, J.M. In Situ phytomanagement with Brassica napus and bio-stabilised municipal solid wastes is a suitable strategy for redevelopment of vacant urban land. Urban For. Urban Green 2020, 47, 126550. [CrossRef]

11. Alvarenga, P.; Mourinha, C.; Farto, M.; Santos, T.; Palma, P.; Sengo, J.; Morais, M.-C.; Cunha-Queda, C. Sewage sludge, compost and other representative organic wastes as agricultural soil amendments: Benefits versus limiting factors. Waste Manag. 2015, 40, 44-52. [CrossRef]

12. Tejada, M.; Gonzalez, J.L. Effects of the application of a compost originating from crushed cotton gin residues on wheat yield under dryland conditions. Eur. J. Agron. 2003, 19, 357-368. [CrossRef]

13. Tilston, E.L.; Pitt, D.; Fuller, M.P.; Groenhof, A.C. Compost increases yield and decreases take-all severity in winter wheat. F Crop. Res. 2005, 94, 176-188. [CrossRef]

14. Courtney, R.G.; Mullen, G.J. Soil quality and barley growth as influenced by the land application of two compost types. Bioresour. Technol. 2008, 99, 2913-2918. [CrossRef] [PubMed]

15. Agegnehu, G.; Bass, A.M.; Nelson, P.N.; Bird, M.I. Benefits of biochar, compost and biochar-compost for soil quality, maize yield and greenhouse gas emissions in a tropical agricultural soil. Sci. Total Environ. 2016, 543, 295-306. [CrossRef] [PubMed]

16. Naeini, S.A.R.M.; Cook, H.F. Influence of municipal compost on temperature, water, nutrient status and the yield of maize in a temperate soil. Soil Use Manag. 2000, 16, 215-221. [CrossRef]

17. Pane, C.; Palese, A.M.; Spaccini, R.; Piccolo, A.; Celano, G.; Zaccardelli, M. Enhancing sustainability of a processing tomato cultivation system by using bioactive compost teas. Sci. Hortic. 2016, 202, 117-124. [CrossRef]

18. Martínez-Blanco, J.; Muñoz, P.; Antón, A.; Rieradevall, J. Life cycle assessment of the use of compost from municipal organic waste for fertilization of tomato crops. Resour. Conserv. Recycl. 2009, 53, 340-351. [CrossRef]

19. Garg, P.; Gupta, A.; Satya, S. Vermicomposting of different types of waste using Eisenia foetida: A comparative study. Bioresour. Technol. 2006, 97, 391-395. [CrossRef]

20. Universidad Pública de Navarra. Leguminosae, Vicia Faba: Haba. Available online: https://www.unavarra.es/herbario/ pratenses/htm/Vici_faba_p.htm (accessed on 4 June 2019).

21. Singh, M.; Upadhyaya, H.D.; Bisht, I.S. Genetic and Genomic Resources of Grain Legume Improvement. 1-Introduction; Elsevier: Oxford, UK, 2013; pp. 1-10.

22. FAO. FAOSTAT Database. Food and Agriculture Organization of the United Nations. Available online: http:/ / www.fao.org/faostat/ en/\#data/QC (accessed on 3 November 2020).

23. Karkanis, A.; Ntatsi, G.; Lepse, L.; Fernández, J.A.; Vågen, I.M.; Rewald, B.; Alsina, I.; Kronberga, A.; Balliu, A.; Olle, M.; et al. Faba Bean Cultivation-Revealing Novel Managing Practices for More Sustainable and Competitive European Cropping Systems. Front. Plant. Sci 2018, 9, 1115. [CrossRef] [PubMed]

24. Pacyna, S.; Schulz, M.; Scherer, H. Influence of sulphur supply on glucose and ATP concentrations of inoculated broad beans (Vicia faba minor L.): Dedicated to Prof. Dr. Dr. h.c. W. Werner on the occasion of his 75th birthday. Biol. Fertil. Soils 2006, 42, 324-329. [CrossRef]

25. Mona, A.M.; Sabah, M.A.; Rehab, A.M. Influence of potassium sulfate on faba bean yield and quality. Aust. J. Basic Appl. Sci. 2011, 5, 87-95.

26. Pötzsch, F.; Lux, G.; Schmidtke, K. Sulphur demand, uptake and fertilization of Vicia faba L. under field conditions. F Crop. Res. 2018, 228, 76-83. [CrossRef]

27. Barłóg, P.; Grzebisz, W.; Łukowiak, R. Faba bean yield and growth dynamics in response to soil potassium availability and sulfur application. F Crop. Res. 2018, 219, 87-97. [CrossRef]

28. Hariadi, Y.; Shabala, S. Screening broad beans (Vicia faba) for magnesium deficiency. II. Photosynthetic performance and leaf bioelectrical responses. Funct. Plant. Biol. 2004, 31, 539-549. [CrossRef]

29. Nebiyu, A.; Diels, J.; Boeckx, P. Phosphorus use efficiency of improved faba bean (Vicia faba) varieties in low-input agro-ecosystems. J. Plant. Nutr. Soil Sci. 2016, 179, 347-354. [CrossRef]

30. Cucci, G.; Lacolla, G.; Summo, C.; Pasqualone, A. Effect of organic and mineral fertilization on faba bean (Vicia faba L.). Sci. Hortic. 2019, 243, 338-343. [CrossRef]

31. Abdelhamid, M.T.; Horiuchi, T.; Oba, S. Composting of rice straw with oilseed rape cake and poultry manure and its effects on faba bean (Vicia faba L.) growth and soil properties. Bioresour. Technol. 2004, 93, 183-189. [CrossRef]

32. Fernández-Luqueño, F.; Reyes-Varela, V.; Martínez-Suárez, C.; Salomón-Hernández, G.; Yáñez-Meneses, J.; Ceballos-Ramírez, J.M.; Dendooven, L. Effect of different nitrogen sources on plant characteristics and yield of common bean (Phaseolus vulgaris L.). Bioresour. Technol. 2010, 101, 396-403. [CrossRef] [PubMed]

33. Urbaser. URBASER, S.A. Available online: https:/ / www.urbaser.com/en/ (accessed on 10 March 2020).

34. BOE-A-2011-13046. Ley 22/2011, de 28 de Julio, de Residuos y Suelos Contaminados. Available online: https:/ / www.boe.es / boe/dias/2011/07/29/pdfs/BOE-A-2011-13046.pdf (accessed on 4 June 2019). 
35. MAPA. Ministerio de Agricultura, Pesca y Alimentación. Métodos Oficiales de Análisis; MAPA: Madrid, Spain, $1994 ;$ Volume 3, p. 162.

36. Hesse, P.R. Total Nitrogen: The Kjeldahl Process. A Texbook of Soil Chemical Analysis; Murray: London, UK, $1971 ;$ p. 520.

37. Bremner, J.M.; Mulvaney, C.S. Nitrogen-Total. In Methods of Soil Analysis; Soil Science Society of America, Inc.: Madison, WI, USA, 1983; pp. 595-624.

38. APHA. Standard Methods for the Examination of Water and Wastewater, 21st ed.; American Public Health Association: Washington, DC, USA; American Water Works Assotiation and Water Environment Federation: Washington, DC, USA, $2005 ;$ p. 874.

39. USEPA. Method 3051A Microwave Assisted Acid Digestion of Sediments, Sludges, Soils, and Oils; US Government: Washington, DC, USA, 2007.

40. Mirshekari, M.; Majnounhosseini, N.; Amiri, R.; Moslehi, A.; Zandvakili, O. Effects of Sowing Date and Irrigation Treatment on Safflower Seed Quality. J. Agric. Sci. Technol. 2013, 15, 505-515.

41. Dualex. Dualex. Available online: https://www.force-a.com/products/dualex (accessed on 9 May 2020).

42. Barker, K.R. Nematode extraction and bioassays. In An Advanced Treatise on Meloidogyne, Vol 2 Methodology; Barker, K.R., Carter, C.C., Sasser, J.N., Eds.; North Carolina State University Graphics: Raleigh, NC, USA, 1985; pp. 19-35.

43. Bongers, T. De Nematoden van Nederland; KNNV-bibliotheekuitgave: Schoorl, The Netherlands, 1988 ; p. 408.

44. Bongers, T. The maturity index: An ecological measure of environmental disturbance based on nematode species composition. Oecologia 1990, 83, 14-19. [CrossRef] [PubMed]

45. Ferris, H.; Bongers, T.; de Goede, R.G.M. A framework for soil food web diagnostics: Extension of the nematode faunal analysis concept. Appl. Soil Ecol. 2001, 18, 13-29. [CrossRef]

46. Ferris, H. Form and function: Metabolic footprints of nematodes in the soil food web. Eur. J. Soil Biol. 2010, 46, 97-104. [CrossRef]

47. IBM Corp. IBM SPSS Statistics for Windows. Available online: https://www.ibm.com/analytics/spss-statistics-software (accessed on 14 June 2019).

48. R Core Team. R: A Language and Environment for Statistical Computing. R Foundation for Statistical Computing. Available online: https: / /www.r-project.org/ (accessed on 17 June 2019).

49. Mady, M.A. Effect of foliar application with yeast extract and zink on fruit setting Faba bean (Vicia faba L). J. Biol. Chem. Environ. Sci. 2009, 4, 109-127.

50. Ece, A.; Duzdemir, O.; Akdag, C.; Uysal, F. Isitmasiz cam serada kis doneminde taze bakla (Vicia faba L.) yetistirme olanaklarinin arastirilmasi (Studies on fresh broad-bean (Vicia faba L.) growing in unheated greenhouse under winter conditions). J. Ataturk Cent. Hortic. Res. Inst. 2004, 33. Available online: https:/ / dergipark.org.tr/en/pub/bahce/issue/3348/46305 (accessed on 4 June 2019).

51. Weldua, Y.; Haileb, M.; Habtegebrielb, K. Effect of zinc and phosphorus fertilizers application on yield and yield components of faba bean (Vicia faba L.) grown in calcaric cambisol of semi-arid northern Ethiopia. J. Soil Sci. Environ. Manag. 2013, 3, 320-326.

52. Reyhan, K.; Topal, N.; Bozoğlu, H. Bakla (Vicia faba L.)'da Farklı Ekim Sıklıklarının Yaprak Alanı ve Verim Unsurlarına Etkisi. Tarla Bitk Merk Araştırma Enstitüsü Derg. 2016, 25, 213.

53. Al-Rifaee, M.; Turk, M.; Al Tawaha, A.R. Effect of Seed Size and Plant Population Density on Yield and Yield Components of Local Faba Bean (Vicia faba L. Major). Int. J. Agric. Biol. 2004, 6, 294-299.

54. De Cillis, F.; Leoni, B.; Massaro, M.; Renna, M.; Santamaria, P. Yield and Quality of Faba Bean (Vicia faba L. var. major) Genotypes as a Vegetable for Fresh Consumption, A Comparison between Italian Landraces and Commercial Varieties. Agriculture 2019, 9, 253. [CrossRef]

55. Salem, A.; EL-Harty, E.; Ammar, M.; Alghamdi, S. Evaluation of Faba Bean (Vicia faba L.) Performance under Various Micronutrients Foliar Applications and Plant Spacing. Life Sci. J. 2014, 11, 1298.

56. Crépon, K.; Marget, P.; Peyronnet, C.; Carrouée, B.; Arese, P.; Duc, G. Nutritional value of faba bean (Vicia faba L.) seeds for feed and food. F Crop. Res. 2010, 115, 329-339. [CrossRef]

57. Al-Jobori, K.; Salim, S. Response of Potato (Solanum Tuberosum) to Foliar Application of Iron, Manganese, Copper and Zinc. IJACS 2018, 7, 358-363.

58. Teixeira, I.; Borém, A.; Andrade, A.; Fontes, R. Manganese and zinc leaf application on common bean grown on a "Cerrado" soil. Sci. Agric. 2004, 61. [CrossRef]

59. Larcher, W. Physiological Plant Ecology: Ecophysiology and Stress Physiology of Functional Groups, 4th ed.; Springer: Berlin/Heidelberg, Germany, 2003.

60. Arena, M.E.; Pastur, G.M.; Lencinas, M.V.; Soler, R.; Bustamante, G. Changes in the leaf nutrient and pigment contents of Berberis microphylla G. Forst. in relation to irradiance and fertilization. Heliyon 2020, 6, e03264. [CrossRef] [PubMed]

61. Kobraee, S. Effect of zinc, iron and manganese fertilization on concentrations of these metals in the stem and leaves of soybean and on the chlorophyll content in leaves during the reproductive development stages. J. Elem. 2012, 21, 395-412. [CrossRef]

62. Santos, E.; Zanchim, B.; Campos, A.; Garrone, R.; Lavres Junior, J. Photosynthesis rate, chlorophyll content and initial development of physic nut without micronutrient fertilization. Rev. Bras. Ciência Solo 2013, 37, 1334-1342. [CrossRef]

63. Zhang, Q.; Zhai, J.; Shao, L.; Lin, W.; Peng, C. Accumulation of Anthocyanins: An Adaptation Strategy of Mikania micrantha to Low Temperature in Winter. Front. Plant. Sci. 2019, 10, 1049. [CrossRef]

64. Nardi, S.; Morari, F.; Berti, A.; Tosoni, M.; Giardini, L. Soil organic matter properties after 40 years of different use of organic and mineral fertilisers. Eur. J. Agron. 2004, 21, 357-367. [CrossRef] 
65. Carmo, D.L.; do Lima, L.B.; de Silva, C.A. Soil Fertility and Electrical Conductivity Affected by Organic Waste Rates and Nutrient Inputs. Rev. Bras Ci $\tilde{A} \backslash$ Textordfemeninencia Do Solo 2016, 40. Available online: http:/ / www.scielo.br/scielo.php?script=sci_arttext\& pid $=$ S0100-06832016000100532\&nrm $=$ iso (accessed on 4 June 2019). [CrossRef]

66. Cavallaro, N.; Padilla, N.; Villarrubia, J. Sewage Sludge Effects on Chemical Properties of Acid Soils. Soil Sci. 1993, 156. Available online: https://journals.lww.com/soilsci/Fulltext/1993/08000/SEWAGE_SLUDGE_EFFECTS_ON_CHEMICAL_ PROPERTIES_OF.1.aspx (accessed on 6 June 2019). [CrossRef]

67. Ozlu, E.; Kumar, S. Response of Soil Organic Carbon, pH, Electrical Conductivity, and Water Stable Aggregates to Long-Term Annual Manure and Inorganic Fertilizer. Soil Sci Soc. Am. J. 2018, 82. [CrossRef]

68. Melero, S.; Madejón, E.; Ruiz, J.C.; Herencia, J.F. Chemical and biochemical properties of a clay soil under dryland agriculture system as affected by organic fertilization. Eur. J. Agron. 2007, 26, 327-334. [CrossRef]

69. USDA. Soil pH-Soil Health Guides for Educators. Available online: https://cropwatch.unl.edu/documents/USDA_NRCS_pH_ guide_edit_6_3_14.pdf (accessed on 16 June 2019).

70. Jensen, E.S.; Peoples, M.B.; Hauggaard-Nielsen, H. Faba bean in cropping systems. F Crop. Res. 2010, 115, 203-216. [CrossRef]

71. Zhao, Z.; Zhang, C.; Li, F.; Gao, S.; Zhang, J. Effect of compost and inorganic fertilizer on organic carbon and activities of carbon cycle enzymes in aggregates of an intensively cultivated Vertisol. PLoS ONE 2020, 15, e0229644. [CrossRef]

72. Soumaré, M.; Demeyer, A.; Tack, F.M.G.; Verloo, M.G. Chemical characteristics of Malian and Belgian solid waste composts. Bioresour. Technol. 2002, 81, 97-101. [CrossRef]

73. Ouédraogo, E.; Mando, A.; Zombré, N.P. Use of compost to improve soil properties and crop productivity under low input agricultural system in West Africa. Agric. Ecosyst. Environ. 2001, 84, 259-266. [CrossRef]

74. BOE. Real Decreto 1310/1990, de 29 de Octubre, por el que se Regula la Utilización de los Lodos de Depuración en el Sector Agrario. Available online: https://www.boe.es/buscar/doc.php?id=BOE-A-1990-26490 (accessed on 16 June 2019).

75. Mutammimah, U.; Minardi, S.; Suryono, S. Organic amendments effect on the soil chemical properties of marginal land and soybean yield. J. Degrad Min. Lands Manag. 2020, 7, 2263-2268. [CrossRef]

76. van den Hoogen, J.; Geisen, S.; Routh, D.; Ferris, H.; Traunspurger, W.; Wardle, D.A.; de Goede, R.G.M.; Adams, B.J.; Ahmad, W.; Andriuzzi, W.S.; et al. Soil nematode abundance and functional group composition at a global scale. Nature 2019, 572, 194-198. [CrossRef] [PubMed]

77. Hlava, J.; Száková, J.; Vadlejch, J.; Čadková, Z.; Balík, J.; Tlustoš, P. Long-term application of organic matter based fertilisers: Advantages or risks for soil biota? A review. Environ. Rev. 2017, 25, 408-414. [CrossRef]

78. Coors, A.; Edwards, M.; Lorenz, P.; Römbke, J.; Schmelz, R.M.; Topp, E.; Waszak, K.; Wilkes, G.; Lapen, D.R. Biosolids applied to agricultural land: Influence on structural and functional endpoints of soil fauna on a short- and long-term scale. Sci. Total Environ. 2016, 562, 312-326. [CrossRef]

79. Li, S.; Zhu, L.; Li, J.; Ke, X.; Wu, L.; Luo, Y.; Christie, P. Influence of long-term biosolid applications on communities of soil fauna and their metal accumulation: A field study. Environ. Pollut. 2020, 260, 114017. [CrossRef] 